\title{
A gene from Alcaligenes denitrificans that confers albicidin resistance by reversible antibiotic binding
}

\author{
W. V. Shiromi Basnayake $\nmid$ and Robert G. Birch \\ Author for correspondence: Robert G. Birch. Tel: +61 7365 3347. Fax: +61 73651699. \\ e-mail: birch@palm.botany.uq.oz.au
}

Department of Botany, The University of Queensland, Brisbane 4072, Australia

\begin{abstract}
Albicidin antibiotics specifically block prokaryote DNA replication. The albicidin resistance gene (albB) cloned from a soil isolate of Alcaligenes denitrificans encodes a $23 \mathrm{kDa}$ protein capable of detoxifying albicidin by reversible binding. This mechanism operates intracellularly to protect DNA replication in albicidin-sensitive Escherichia coli expressing the cloned resistance gene, which can be induced fivefold in the presence of $1.5 \mu \mathrm{g}$ albicidin $\mathrm{ml}^{-1}$ in the surrounding medium. The coding region of 621 bp has regions with partial DNA sequence homology to an albicidin resistance gene (albA) from Klebsiella oxytoca, but with rearrangements and frame-shifts resulting in loss of protein homology. There is a short region of $\mathbf{N}$-terminal homology between the albicidin resistance (Alb') proteins from A. denitrificans and $K$. oxytoca, although the two genes use different codons for shared amino acids. The $\mathrm{N}$-terminal homology suggested a common functional domain; this was confirmed by deletion analysis, translational fusions and albicidin binding by a synthetic oligopeptide. Antibiotic binding provides a high level of albicidin resistance in $E$. coli. The gene appears to be a useful candidate for transfer to plants to protect plastid DNA replication from inhibition by albicidin phytotoxins involved in sugarcane leaf scald disease.
\end{abstract}

Keywords: Alcaligenes denitrificans, antibiotic binding, albicidin resistance, alb gene

\section{INTRODUCTION}

The phytopathogen Xanthomonas albilineans, which causes leaf scald disease of sugarcane, produces a family of toxins that selectively block DNA replication in bacteria and chloroplasts (Birch \& Patil, 1985b, 1987b). The major antibiotic produced by $X$. albilineans in culture is a low molecular mass aromatic compound called albicidin, which is rapidly bactericidal at concentrations between 1 and $100 \mathrm{ng} \mathrm{ml}^{-1}$ to a range of Gram-positive and Gramnegative bacteria. Near the minimum inhibitory concentration against Escherichia coli, albicidin causes a rapid and complete block to DNA replication without binding to or damaging DNA, indicating likely interaction with a DNA replication protein (Birch \& Patil, 1985b; Birch et al., 1990). There is no cross-resistance between albicidin

†Present address: Sugarcane Research Institute, Uda Walawe, Sri Lanka. Abbreviation: Albr, albicidin-resistant, albicidin resistance.

The GenBank accession number for the nucleotide sequence reported in this paper is U13008. and other antibiotics affecting DNA replication. At $8 \mu \mathrm{g}$ $\mathrm{ml}^{-1}$, the compound shows no cytotoxicity to mammalian cells in tissue culture (Birch \& Patil, 1985a). Albicidins are therefore of interest as potential clinical antibiotics and as tools to study prokaryotic DNA replication.

Albicidins produced by $X$. albilineans cause the characteristic chlorotic symptoms in emerging leaves of sugarcane with leaf scald disease, by preferentially inhibiting DNA replication in differentiating plastids (Birch \& Patil, $1983,1987 \mathrm{a}, \mathrm{b})$. This mode of action is unique among phytotoxins, and provides a rare example of a known mechanism of development of a plant disease from the molecular level through to visible symptom expression. Mutants of $X$. albilineans which do not produce albicidins have failed to produce any systemic disease symptoms in inoculated sugarcane (Birch \& Patil, 1987a). Albicidin resistance may therefore convey leaf scald disease resistance in sugarcane. The recent development of techniques for gene transfer into sugarcane cells (Franks \& Birch, 1991; Rathus \& Birch, 1992), and production of transgenic sugarcane plants (Bower \& Birch, 1992), 
creates an opportunity to test novel genes for disease resistance in this crop.

Albicidin is effective at very low concentrations against $E$. coli because it is rapidly concentrated within cells by illicit transport through the $t s x$-encoded outer-membrane channel normally involved in nucleoside uptake (Birch et al., 1990). Although albicidin has a molecular mass three to four times that of common nucleosides, and partial characterization by proton and ${ }^{13} \mathrm{C}$ NMR spectroscopy reveals no apparent nucleoside moiety (Birch \& Patil, 1985a), the compound apparently uses the nucleoside binding site of the Tsx channel for efficient flux across the E. coli outer membrane. Albicidin resistance results from loss of the mechanism of albicidin transport through the outer membrane (Birch et al., 1990), and is accompanied by diminished capacity for Tsx-mediated deoxynucleoside uptake (Fsihi et al., 1993). The mechanism of albicidin transport across the inner membrane is unknown.

A dominant $\mathrm{Alb}^{\mathrm{r}}$ gene cloned from Klebsiella oxytoca encodes a $25 \mathrm{kDa}$ protein which binds to albicidin in vitro to form a complex without antibiotic activity, but without catalysing further chemical modification of the albicidin. Binding of the antibiotic is transiently blocked by an excess of ATP, but not by other nucleosides or nucleotides (Walker et al., 1988). This was the first example of antibiotic resistance due to a non-catalytic antibiotic binding protein. The normal function of the $\mathrm{Alb}^{\mathbf{r}}$ protein in $K$. oxytoca remains unknown.

We report here that Alcaligenes denitrificans also has a gene for an albicidin binding protein which confers albicidin resistance when expressed in $E$. coli. The $A$. denitrificans gene is distinct from the one previously demonstrated in $K$. oxytoca, but shows a short region of amino acid homology at the $\mathrm{N}$ terminus, which appears to play a role in albicidin binding.

\section{METHODS}

Bacterial strains and plasmids. The bacterial strains and plasmids used in this work are given in Table 1. Albicidinresistant $\left(\mathrm{Alb}^{\mathrm{r}}\right)$ bacteria were isolated from diluted suspensions of soil from grassland at Samford, Queensland, by plating onto
Luria medium (LM; Miller, 1972) containing $100 \mathrm{ng}$ albicidin $\mathrm{ml}^{-1}$. Determinative tests were performed using routine procedures (Krieg \& Holt, 1984) and API 20NE test strips.

Media and growth conditions. The nutrient medium used for E. coli, $A$. denitrificans and other isolated soil bacteria was LM. Where necessary this was solidified with $1.5 \%$ agar. Cultures of E. coli were incubated at $35^{\circ} \mathrm{C}$, and other bacteria at $29^{\circ} \mathrm{C}$. Broth cultures were aerated by shaking at 200 r.p.m. on an orbital shaker.

Inactivation of albicidin by isolated soil bacteria. Albicidins were produced and assayed as described previously (Birch et al., 1990). The mixture of albicidins obtained after HW-40(S) chromatography was used in these experiments. Dose-response relationships to albicidin were determined as described previously (Birch \& Patil, 1985b), except that basal layers were of LM agar, and the sample volume per well was $15 \mu \mathrm{l}$.

Albicidin remaining in culture supernatants was determined after overnight growth at $29^{\circ} \mathrm{C}$ in LM broth containing $100 \mathrm{ng}$ albicidin $\mathrm{ml}^{-1}$. To test for production of extracellular products able to inactivate albicidin, isolates were grown in LM broth containing $100 \mathrm{ng}$ albicidin $\mathrm{ml}^{-1}$. Each day for $7 \mathrm{~d}, 15 \mu \mathrm{l}$ of cellfree culture supernatant was removed, mixed with $50 \mathrm{ng}$ albicidin and assayed for antibiotic activity. To measure intracellular accumulation of albicidin, cells grown as described above in the presence of albicidin were disrupted by sonication as described below, and assayed for antibiotic activity in the cell extract.

Cloning and sequencing of the albB gene. A genomic library of $A$. denitrificans SO-9 was prepared by cloning fragments from partial Sau3AI endonuclease digests of chromosomal DNA into the BamHI site of cosmid pHC79, followed by transfection into E. coli 294, using published protocols (Priefer et al., 1984) and biochemicals from Promega. Recombinant clones were selected on LM agar containing carbenicillin. Alb ${ }^{r}$ clones were identified by patching on LM agar supplemented with albicidin, and T6 sensitivity was confirmed by cross streaking. Routine techniques were used for subcloning into pUC19 and pBluescriptII SK + vectors (Sambrook et al., 1989).

Two $\mathrm{Alb}^{\mathrm{r}}$ clones (pSB6, pSB9) and five $\mathrm{Alb}^{\mathrm{s}}$ clones obtained after Exonuclease III digestion (pSB6-I, pSB7, pSB8, pSB10, $\mathrm{pSB} 11$ ) were used to obtain the complete sequence from both strands of the isolated $a l b B$ gene. For dideoxy sequencing (Chen \& Seeburg, 1985), RNA-free, double-stranded, closed circular DNA templates were denatured in alkali and annealed to either T7 universal primer or reverse primer according to the

\section{Table 1. Bacterial strains and plasmids}

Plasmids constructed in this work are shown in Fig. 1.

\begin{tabular}{|c|c|c|}
\hline Strain or plasmid & Genotype or feature & Reference or source \\
\hline A. denitrificans SO-9 & $\mathrm{Alb}^{\mathrm{r}}$ & This work \\
\hline E. coli $\mathrm{DH} 5 \alpha$ & 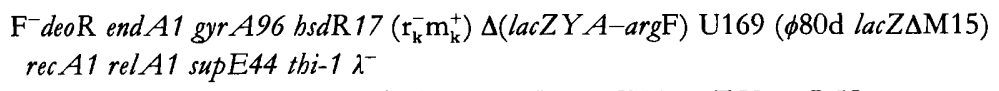 & Sambrook et al. (1989) \\
\hline E. coli LE 392 & $\mathrm{~F}^{-}$galK2 galT22 hsdR $514\left(\mathrm{r}_{\mathrm{k}}^{-} \mathrm{m}_{\mathrm{k}}^{+}\right) \operatorname{lac} Y 1 \operatorname{metB} 1 \operatorname{supE} 44 \operatorname{supF} 58 \operatorname{trp} \mathrm{R} 55 \lambda^{-}$ & \\
\hline E. coli UQM70 & Prototrophic, Val ${ }^{\mathrm{r}}$ wild type & Birch et al. (1990) \\
\hline E. coli $294 \mathrm{RecA}^{-}$ & $\mathrm{F}^{-} b s d \mathrm{R} 17\left(\mathrm{r}_{\mathrm{k}}^{-} \mathrm{m}_{\mathrm{k}}^{+}\right) \operatorname{rec} A$ end $A 1$ thi-1 supE44 $\lambda^{-}$ & Uhlin et al. (1983) \\
\hline \multicolumn{3}{|l|}{ Plasmid } \\
\hline $\mathrm{pBS} \mathrm{SK}+$ & $A p^{r}$ sequencing vector & Stratagene \\
\hline $\mathrm{pHC79}$ & $A p^{r} T^{r}{ }^{r}$ cosmid vector & Hohn \& Collins (1980) \\
\hline pUC19 & $A p^{r}$ cloning vector & Vieira \& Messing (1982) \\
\hline
\end{tabular}


manufacturer's instructions (Pharmacia: T7 sequencing kit), except that primer annealing was carried out for $10 \mathrm{~min}$ at $70{ }^{\circ} \mathrm{C}$ and gradually cooled to room temperature over $20 \mathrm{~min}$ to reduce secondary structures.

Preparation of cell extracts containing the albB gene product. E. coli $\mathrm{DH} 5 \alpha$ carrying plasmid $\mathrm{pUC19}$ or $\mathrm{pSB} 4$ was grown overnight at $37{ }^{\circ} \mathrm{C}$ then mixed with albicidin at a final concentration of $1.5 \mu \mathrm{g} \mathrm{ml}^{-1}$ and incubated for a further $5 \mathrm{~h}$. To examine the inducibility of albicidin resistance, cell extracts were collected at intervals after addition of albicidin. Cells were harvested from $25 \mathrm{ml}$ of culture by centrifuging at $15000 \mathrm{~g}$ for $10 \mathrm{~min}$, washed in $10 \mathrm{mM}$ sodium phosphate buffer $(\mathrm{pH} \mathrm{7.8)}$ or TEMM extraction buffer [ $10 \mathrm{mM}$ tris(hydroxymethyl)aminomethane $\mathrm{pH} 7 \cdot 0,10 \mathrm{mM}$ EDTA, $10 \mathrm{mM} \mathrm{MgCl}_{2}$ and $2 \mathrm{mM} \beta$ mercaptoethanol] and recentrifuged at $15000 \mathrm{~g}$ for $5 \mathrm{~min}$. The cell pellet was resuspended in the same buffer to a final volume of $125 \mu \mathrm{l}$, and cells were disrupted by sonication on ice, with a microprobe at $50 \%$ duty cycle, applying $8 \mathrm{~s}$ sonication periods with an output of $25-45 \mathrm{~W}$, for 6 min (Branson model 250 sonifier). Cell disruption was confirmed by phase contrast microscopy, and cell debris was removed by centrifugation at $15000 \mathrm{~g}$ for $30 \mathrm{~min}$. Approximately $100 \mu \mathrm{l}$ of sonicated cell supernatant (containing $10-12 \mu \mathrm{g}$ protein $\mu \mathrm{l}^{-1}$ ) was obtained from a $50 \mathrm{ml}$ stationary phase culture, and stored at $-20^{\circ} \mathrm{C}$ in small samples for use as cell extract. Protein concentrations in cell extracts were measured by dye-binding (Bradford, 1976), using bovine serum albumin (BSA) for calibration.

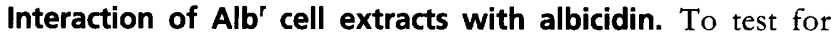
ability to inactivate albicidin, cell extracts containing $10 \mu \mathrm{g}$ total protein were mixed with 15-75 $\mathrm{ng}$ of albicidin in a final volume of $15 \mu \mathrm{l}$ and antibacterial activity was assayed immediately. To test for heat-reversible binding of albicidin to the albB gene product, cell extract containing $100 \mu \mathrm{g}$ total protein was mixed with $12 \mathrm{ng}$ albicidin in a final volume of $30 \mu \mathrm{l}$. One half of the mixture was treated at $100^{\circ} \mathrm{C}$ for $15 \mathrm{~min}$, then both the boiled and unboiled samples were assayed for antibacterial activity. Mixtures were incubated for intervals up to $1 \mathrm{~h}$ before boiling to detect progressive inactivation, indicative of catalytic activity. Materials tested as cofactors for catalytic inactivation of albicidin by cell extracts were $1 \mathrm{mM} \mathrm{ATP}, 1 \mathrm{mM} \mathrm{NAD}^{+}, 1 \mathrm{mM} \mathrm{Mg}^{2+}$ and $100 \mu \mathrm{M}$ each of reducing agents dithiothreitol or $\beta$-mercaptoethanol.

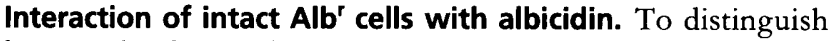
between binding and catalytic inactivation of albicidin in intact cells, overnight cultures of $E$. coli $\mathrm{DH} 5 \alpha(\mathrm{pSB} 6)$ and $A$. denitrificans SO-9 were mixed with an equal volume of LM containing albicidin. Samples were removed at intervals and placed on ice, or boiled for $15 \mathrm{~min}$ to release bound albicidin then placed on ice. At the end of the sampling period, all samples were assayed for remaining albicidin activity.

Isolation and characterization of the Alb' protein. Denaturing one-dimensional (1D) PAGE was performed on $100 \mu \mathrm{g}$ of cell extract, using linear acrylamide gradients [15-20\% of $39 \%$ (w/v) acrylamide $/ 1 \%$ (w/v) $N^{\prime} N$-methylenebisacrylamide, $100 \mathrm{mM}$ sucrose, $50 \mathrm{mM}$ Tris $/ \mathrm{HCl}, \mathrm{pH} 8 \cdot 3,0 \cdot 1 \%(\mathrm{w} / \mathrm{v}) \mathrm{LiDS}$, $0.05 \%(\mathrm{w} / \mathrm{v})$ ammonium persulphate and $0.001 \%(\mathrm{v} / \mathrm{v})$ $N, N, N^{\prime}, N^{\prime}$-tetramethylethylenediamine (TEMED)] with $8 \%$ acrylamide stacking gels on a slab gel apparatus (Bio-Rad Protean II) at a constant current of $12 \mathrm{~mA}$ for $16 \mathrm{~h}$ per gel at $4{ }^{\circ} \mathrm{C}$ (Ryrie, 1983). Molecular mass markers were bovine serum albumin $(66 \cdot 2 \mathrm{kDa})$, ovalbumin $(42 \cdot 7 \mathrm{kDa})$, glyceraldehyde-3phosphate dehydrogenase $(36 \mathrm{kDa})$, carbonic anhydrase $(26 \mathrm{kDa})$, trypsinogen $(24 \mathrm{kDa})$ and lysozyme $(14 \cdot 4 \mathrm{kDa}) .2 \mathrm{D}$ PAGE was performed as described by Holloway \& Arundel (1988).
1D-gel electrophoresis of cell extracts under non-denaturing conditions was carried out on linear acrylamide gradients (3.5-27\% of $39 \%$ acrylamide $/ 1 \% \quad N^{\prime} N$-methylenebisacrylamide) with $3.5 \%$ acrylamide stacking gels, without LiDS in the gel mix or electrophoresis buffers. The molecular mass markers were apoferritin (dimer $880 \mathrm{kDa}$; monomer $440 \mathrm{kDa}$ ) and BSA (dimer $132 \mathrm{kDa}$; monomer $66 \mathrm{kDa}$ ). Electrophoresis was carried out at a constant current of $12 \mathrm{~mA}$ for $16 \mathrm{~h}$ per gel at $4{ }^{\circ} \mathrm{C}$. Novel bands from cell extracts from E. coli DH $\alpha \alpha(\mathrm{pSB} 4)$ were excised and assayed for the ability to inactivate albicidin.

Electrophoretic transfer onto PVDF membrane was carried out in a Hoeffer electroblotting apparatus at a constant current of $60 \mathrm{~V}$ for $4 \mathrm{~h}$ at $15^{\circ} \mathrm{C}$. The desired protein band was excised from the PVDF membrane and the $\mathrm{N}$-terminal protein sequence was determined by Edman degradation, using a gas-phase protein sequencer (Applied Biosystems model 407A) at the Brisbane Centre for Protein and Nucleic Acid Research.

Albicidin binding by a synthetic oligopeptide. An oligopeptide corresponding to the first 20 amino acids at the $\mathrm{N}$ terminus of the $a l b B$ gene product was synthesized at the Brisbane Centre for Protein and Nucleic Acid Research, using 'tea bag' solid phase synthesis (Houghten, 1985). The product was $60-70 \%$ pure as judged by analytical HPLC, with the remainder consisting of various single amino acid deletions. Ability to inactivate albicidin was tested as described above for extracts.

\section{RESULTS}

\section{Selection and identification of Albr bacteria}

Of 19 Gram-negative $\mathrm{Alb}^{\mathrm{r}}$ bacterial isolates from soil samples, six isolates substantially reduced albicidin activity in the culture medium during overnight incubation. Two isolates (SO-8 and SO-9) removed all albicidin from their culture medium during overnight growth and accumulated no intracellular albicidin, whereas all other isolates partially depleted albicidin in the growth medium and showed some albicidin within cells. No isolates were capable of extracellular detoxification of albicidin in young cultures. Two isolates (SO-8 and SO-9) were able to inactivate albicidin extracellularly in stationary phase cultures, and this capacity increased as cultures aged from 2 to $6 \mathrm{~d}$. These two isolates were also most resistant to albicidin, with minimum inhibitory concentrations $10^{3}$ fold higher than E. coli Q358. Isolate SO-8 was resistant to kanamycin, ampicillin, tetracycline and rifampicin. Isolate SO-9 was sensitive to these antibiotics, and was chosen for further characterization.

The cells of isolate SO-9 from broth culture were Gramnegative, non-spore-forming rods, $0.5-0.7 \mu \mathrm{m}$ in diameter and $1.8-2.5 \mu \mathrm{m}$ in length, with 4-8 peritrichous flagella of 20-22 nm diameter. An inert reaction resulted in the test for oxidation or fermentation of glucose in Hugh and Leifson's medium. The organism was positive in tests for oxidase, reduction of nitrates to nitrites and $\mathrm{N}_{2}$, metabolism of mannitol, gluconate, adipate, malate, citrate and phenyl acetate, and accumulation of intracellular polyhydroxybutyrate (PHB) under conditions of nitrogen starvation. The organism was negative in tests for indole formation, arginine dihydrolase, urease, $\beta$-galactosidase, protease, chitinase, esculin hydrolysis, metabolism of fructose, arabinose, mannose, $\mathrm{N}$-acetyl glucosamine, 


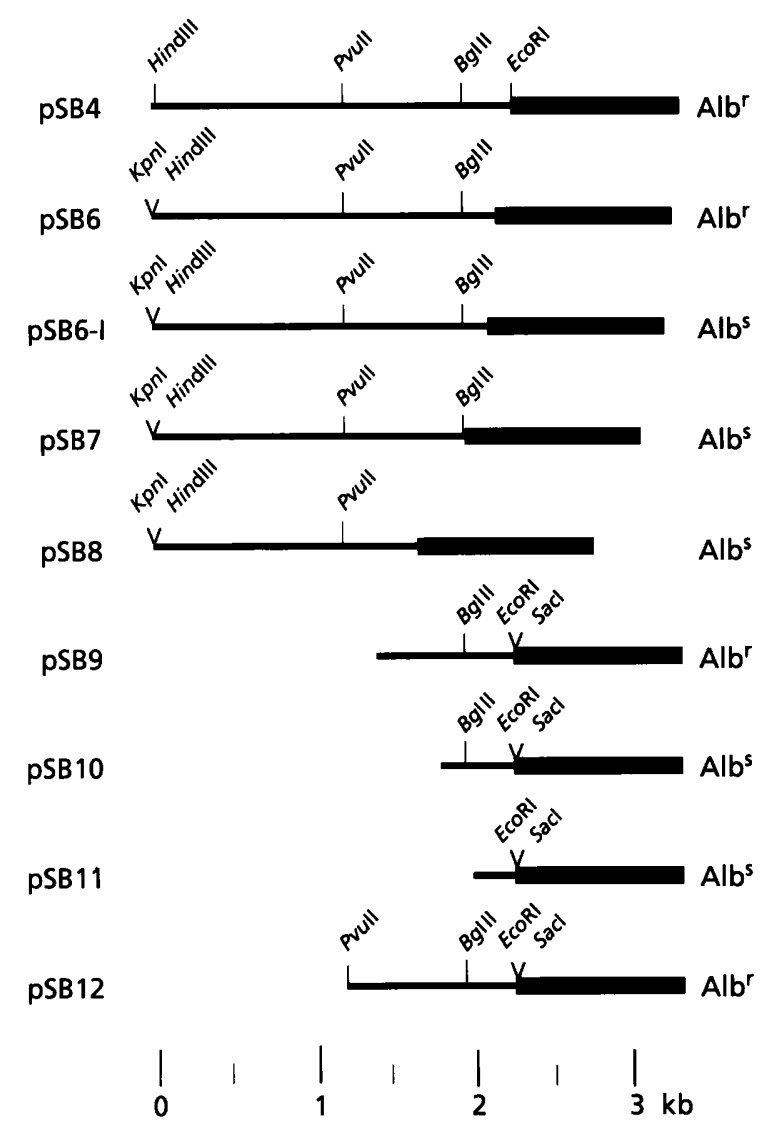

Fig. 1. Restriction endonuclease map of pSB4 and its derivatives. The cloning vector pBluescriptll SK+ (pUC19 for pSB4) is indicated by a heavy line. In all cases, except pSB4, the lac promoter would direct transcription into the insert from right to left. Albicidin resistance or sensitivity of $E$. coli $\mathrm{DH} 5 \alpha$ containing each plasmid and grown on medium without IPTG is indicated.

maltose, and caprate, and pigment production on King B medium. The G+C content of the DNA was $69 \cdot 5-$ $70 \mathrm{~mol} \%$. These features are sufficient for identification of isolate SO-9 as A. denitrificans subsp. denitrificans (Krieg \& Holt, 1984). Ability to metabolize mannitol was the only feature in which isolate $\mathrm{SO}-9$ differed from the species description.

\section{Cloning of the Alb' gene}

An $\mathrm{Alb}^{\mathrm{r}}$ clone containing a $27.7 \mathrm{~kb}$ insert in cosmid pHC79 was recovered from a cosmid genomic library of $A$. denitrificans SO-9 in E. coli $294 \mathrm{RecA}^{-}$. From this cosmid, a $2.3 \mathrm{~kb}$ fragment from digestion with EcoRI and HindIII was inserted into pUC19, to obtain pSB4 which conferred albicidin resistance on $E$. coli $\mathrm{DH} 5 \alpha$. A range of subclones of pSB4 was produced by digestion with EcoRI, HindIII, PvuII and Exonuclease III, in the cloning vector pBluescript SK+ (Fig. 1). Each of these plasmids was transformed into $E$. coli $\mathrm{DH} 5 \alpha$, and the sensitivity of each to albicidin was determined (Table 2). All of these clones remained sensitive to bacteriophage $\mathrm{T} 6$, indicating no interference with the Tsx pore involved with albicidin uptake. The albB gene was located on a $1.1 \mathrm{~kb}$ EcoRIPvuII fragment from $\mathrm{pSB} 4$. Clones with deletions into this region allowed complete sequencing of both strands of the $a l b B$ gene.

\section{Albicidin inactivation by cell-free extracts from $E$. coli expressing the cloned albB gene}

Antibiotic activity up to $30 \mathrm{ng}$ of albicidin was completely abolished when mixed with E. coli $\mathrm{DH} 5 \alpha(\mathrm{pSB} 4)$ cell extract $\left(\mathrm{Alb}^{\mathrm{r}}\right)$ containing $10 \mu \mathrm{g}$ cellular protein prepared in TEMM buffer, but extracts prepared in sodium phosphate buffer failed to inactivate albicidin. At higher albicidin concentrations, there was no progressive antibiotic inactivation by cell extracts during extended incubation in the presence of the tested cofactors. Ability of cell extracts to inactivate albicidin was abolished within $10 \mathrm{~min}$ at temperatures above $55^{\circ} \mathrm{C}$. Albicidin inactivation was not due to non-specific adsorption of the antibiotic to proteins, as only slight loss of antibiotic activity resulted in mixtures of albicidin with cell extracts from E. coli DH5 $\alpha$ (pBluescript) (Fig. 2).

Albicidin is fairly heat stable, but albicidin-protein mixtures generally show reduced activity upon boiling, probably due to loss of albicidin in the denatured protein pellet (e.g. pBluescript + boiling in Fig. 2). In contrast, mixtures of albicidin and cell extract from $E$. coli $\mathrm{DH} 5 \alpha(\mathrm{pSB} 4)$ or DH5 $\alpha(\mathrm{pSB} 12)$, which showed no measurable antibiotic activity before heating, showed substantially restored albicidin activity upon boiling. This indicates release of albicidin upon denaturation of a binding protein encoded by the albB gene cloned from $A$. denitrificans. Extended incubation of albicidin in E. coli DH5 $\alpha(\mathrm{pSB} 12)$ cell extract before boiling did not result in any progressive decrease in recovered antibiotic activity upon boiling (Fig. 2), indicating no catalytic activity of the binding protein in albicidin inactivation under these conditions.

\section{Reversible albicidin binding in intact cells}

There was no evidence of catalytic inactivation of albicidin in intact cells expressing the albB gene. Albicidin was rapidly removed from the culture medium by $E$. coli DH5 $\alpha(\mathrm{pSB} 6)$, but antibiotic activity was recovered by boiling the cells, $5 \mathrm{~h}$ after removal of all activity from the culture medium. $A$. denitrificans SO-9 removed albicidin from the culture medium more slowly, but boiling also released albicidin from these cells after $5 \mathrm{~h}$ incubation.

\section{Isolation and characterization of the albicidin resistance gene product}

A single novel protein band was present in the cell extracts of E. coli DH5 $\alpha(\mathrm{pSB} 4)$ but absent in cell extracts of DH5 $\alpha(\mathrm{pUC19})$ after 1D-LiDS-PAGE. This novel protein appeared as a single spot at $23 \mathrm{kDa}$ after $2 \mathrm{D}$ PAGE, and as a $23 \mathrm{kDa}$ band after native PAGE (Fig. 3). When protein bands were excised from the native PAGE gel, only the gel fragment containing the $23 \mathrm{kDa}$ protein 
Table 2. Sensitivity to albicidin of $A$. denitrificans SO-9 and of $E$. coli $\mathrm{DH} 5 \alpha$ containing subclones of the SO-9 albB gene

Sensitivity of bacterial strains to albicidin was measured as zone width ( $\mathrm{mm}$ ) surrounding a $4 \mathrm{~mm}$ diameter well containing albicidin at the concentrations given $\left(\mu \mathrm{g} \mathrm{ml}^{-1}\right)$. Data are means of two replicates. All plasmids were contained in E. coli DH5 $\alpha$. NT, not tested.

\begin{tabular}{|c|c|c|c|c|c|c|c|}
\hline \multirow[t]{2}{*}{ Clone or strain } & \multirow[t]{2}{*}{ IPTG } & \multicolumn{6}{|c|}{ Sensitivity to albicidin doses } \\
\hline & & $5 \cdot 0$ & $3 \cdot 0$ & 1.0 & 0.5 & $0 \cdot 1$ & 0.01 \\
\hline E. coli $\mathrm{DH} 5 \alpha$ & \pm & NT & NT & $8 \cdot 7$ & $7 \cdot 6$ & $4 \cdot 4$ & $2 \cdot 8$ \\
\hline pSB4 & - & $2 \cdot 0$ & 0 & 0 & 0 & 0 & 0 \\
\hline pSB6 & - & $2 \cdot 2$ & 0 & 0 & 0 & 0 & 0 \\
\hline pSB6-I & + & $4 \cdot 0$ & $3 \cdot 5$ & $1 \cdot 0$ & $0 \cdot 2$ & 0 & 0 \\
\hline pSB6-I & - & NT & NT & $8 \cdot 5$ & $7 \cdot 2$ & $4 \cdot 5$ & $2 \cdot 5$ \\
\hline pSB7 & \pm & NT & $\mathrm{NT}$ & $8 \cdot 4$ & $5 \cdot 9$ & $3 \cdot 7$ & $2 \cdot 1$ \\
\hline pSB8 & \pm & NT & NT & 8.6 & $7 \cdot 1$ & $4 \cdot 0$ & $2 \cdot 5$ \\
\hline pSB9 & - & $2 \cdot 0$ & 0 & 0 & 0 & 0 & 0 \\
\hline pSB10 & \pm & NT & NT & $8 \cdot 4$ & $7 \cdot 2$ & $3 \cdot 6$ & $2 \cdot 2$ \\
\hline pSB11 & \pm & NT & NT & $8 \cdot 7$ & $7 \cdot 4$ & $4 \cdot 3$ & $2 \cdot 8$ \\
\hline $\mathrm{pSB} 12$ & - & $2 \cdot 0$ & 0 & 0 & 0 & 0 & 0 \\
\hline A. denitrificans SO-9 & - & $2 \cdot 2$ & $1 \cdot 3$ & 0 & 0 & 0 & 0 \\
\hline
\end{tabular}

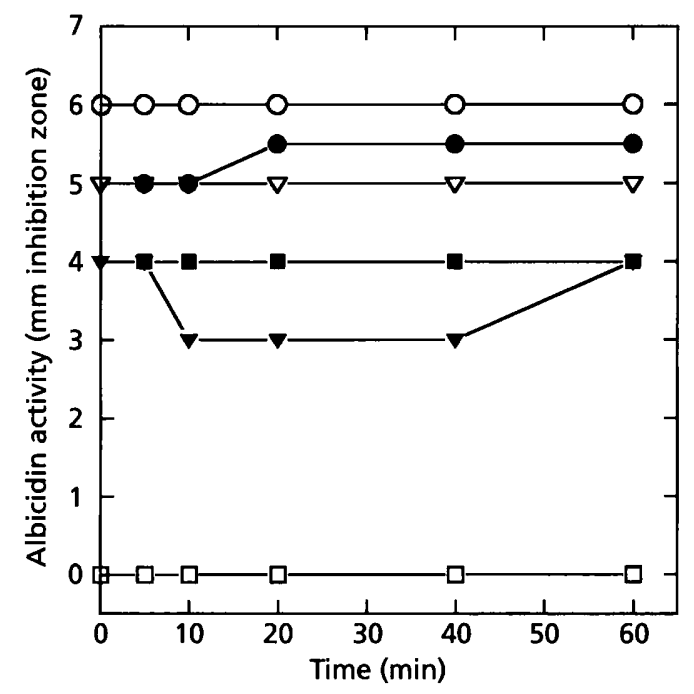

Fig. 2. Effect of extended incubation on reversible inactivation of albicidin by extracts of cells expressing the albB gene. Open symbols indicate samples assayed without boiling, closed symbols indicate samples boiled then assayed. Circles, TEMM buffer control; triangles, $E$. coli DH5 $\alpha$ (pBluescript) control; squares, E. coli DH5 $\alpha$ (pSB12) (expressing albB gene).

was able to inactivate albicidin. The similar protein band obtained under denaturing and native conditions indicates that the albicidin resistance protein is a monomer consisting of a single subunit. The first 26 amino acid residues from the $\mathrm{N}$ terminus of the isolated $23 \mathrm{kDa}$ protein, revealed by Edman degradation, were Met-Tyr-Asp-LysTyr-Phe-Ser-Arg-Glu-Glu-Leu-Ala-Arg-Leu-Pro-LeuTyr-Thr-Arg-Gly-Pro-Asp-Gly-Asp-Pro-Ser. This N-terminal sequence does not have the general features of a signal peptide. The full amino acid composition deduced

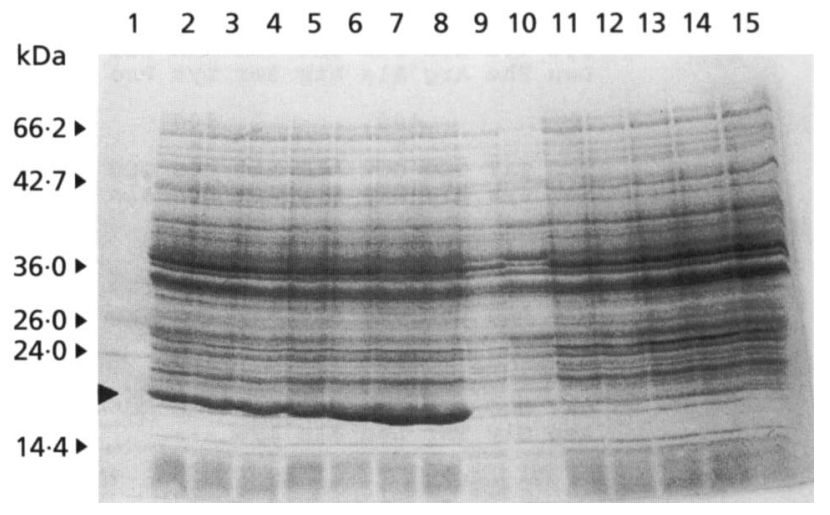

Fig. 3. LiDS-PAGE of protein extracts from cells of $E$. coli $\mathrm{DH} 5 \alpha$. Lanes: 1, molecular mass markers (kDa); $2-15$, protein extracts of $E$. coli DH5 $\alpha$ containing pSB4 (2-8) or pUC19 (9-15) prepared at intervals of $0,1,2,3,4,5$ and $6 \mathrm{~h}$ after exposure to albicidin. Lanes 9 and 10 were loaded with $80 \mu \mathrm{g}$ total protein. All other lanes were loaded with $100 \mu \mathrm{g}$ total protein. The position of the Albr protein is indicated by an arrowhead.

from the nucleotide sequence of the cloned gene (Fig. 4) contained $16.85 \%$ hydrophobic residues (Kyte \& Doolittle, 1982) which were mostly scattered from the middle to the end of the sequence. The predominantly hydrophilic character and the absence of a signal peptide indicate an intracellular protein (Lewin, 1990).

\section{Albicidin-induced accumulation of the resistance gene product}

Cell-free extracts from E. coli DH5 $\alpha(\mathrm{pSB} 4)$ cultures exposed to $1.5 \mu \mathrm{g}$ albicidin $\mathrm{ml}^{-1}$ for $6 \mathrm{~h}$ during early stationary phase showed approximately fivefold greater 


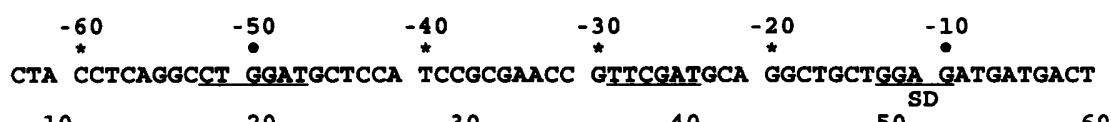

$\begin{array}{llllll}10 & 20 & 30 & 40 & 50 & 60\end{array}$

ATG TAT GAT AAA TAT TTT TCC CGA GAA GAA CTG GCG CGT TTA CCC CTA TAC ACC CGA GGg Met Tyr Asp Lys Tyr phe ser Arg Glu Glu Leu Ala Arg Leu Pro Leu Tyr Thr Arg Gly

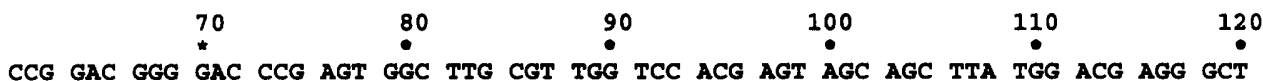
Pro Asp Gly Asp pro Ser Gly Leu Arg Trp Ser Thr Ser Ser Ser Leu Trp Thr Arg Ala

$\begin{array}{llllll}130 & 140 & 150 & 160 & 170 & 180\end{array}$
GGC CAg GGa GGC tat ACC GCG CCA ACT TGC CAT CGC TGG CTG GAa CTG tCG TCG CGa tac Gly Gln Gly Gly Tyr Thr Ala pro Thr Cys His Arg Trp Leu glu Leu Ser Ser Arg Tyr

$1902 \quad 200 \quad 210 \quad 220 \quad 230 \quad 20$
CAA CGG CGA TCC GCG CTT GTT GGT GAA GCT GAA CCA AAT GCA CGA GCA GGA GCC CGA CAT Gln Arg Arg Ser Ala leu val Gly Glu Ala Glu pro Asn Ala Arg Ala Gly Ala Arg His

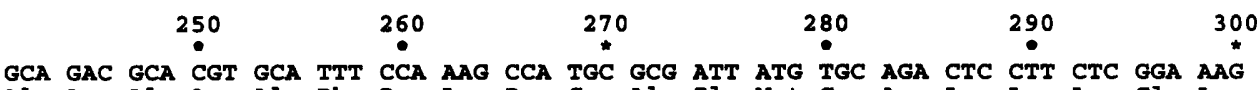
Ala Asp Ala Arg Ala phe pro Lys Pro Cys Ala Ile Met Cys Arg Leu Leu Leu Gly Lys

$\begin{array}{llllll}310 & 320 & 330 & 340 & 350 & 360\end{array}$

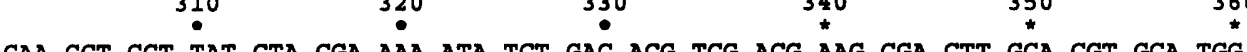
Gln Ala Ala tyr Leu Arg Lys Ile Ser Asp Thr Ser Thr Lys Arg Lou Ala Arg Ala Trp $\begin{array}{ccccccc}370 & 380 & 360 & 400 & 410 & 420 \\ \text { CGC AGC ATT } & \text { ACT GCG ACA GAT CCT GGA GTG GCC ACC TTA } & \text { TCG CAG AGG TCC GGA ACG CTA }\end{array}$ Arg Ser Ile Thr Ala Thr Asp pro Gly val Ala Thr Leu Ser Gln Arg Ser Gly Thr Leu

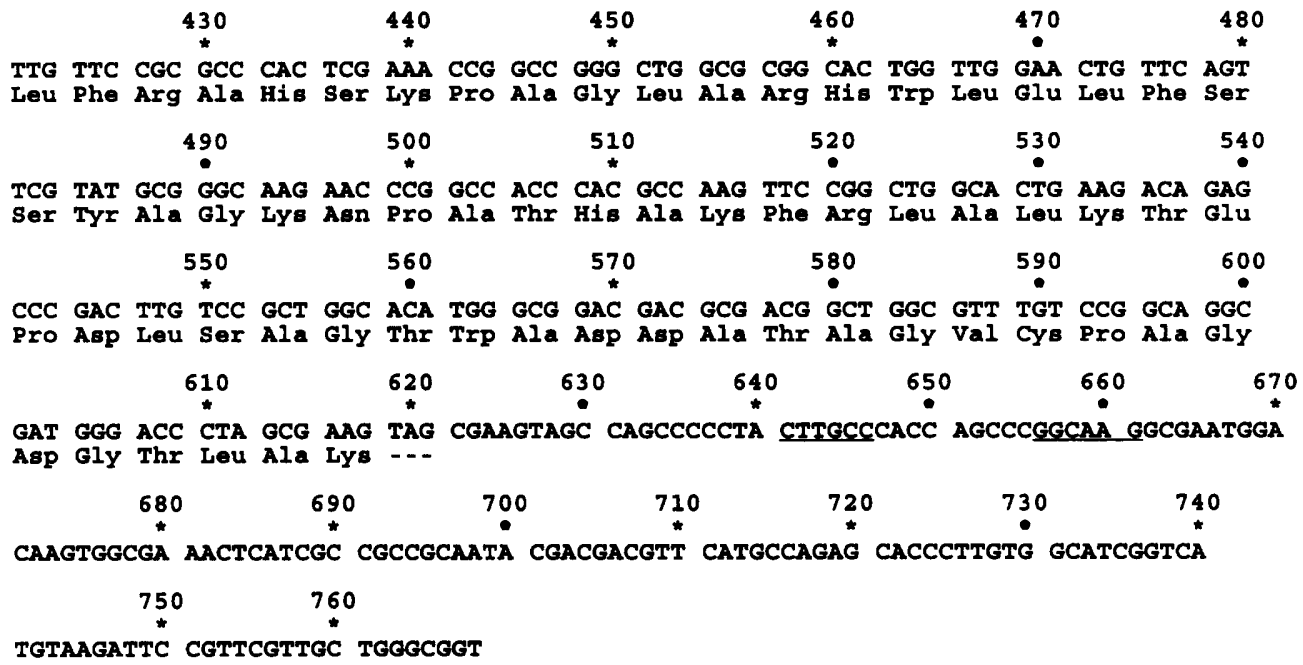

Fig. 4. Nucleotide sequence of the $a l b B$ gene and the predicted amino acid sequence of its gene product. The sequence is numbered commencing at the first base of the translation initiation codon; bases $5^{\prime}$ to the initiation codon have negative numbers. The core regions of the putative promoter are underlined in the -20 to -60 region, as is a SD sequence from -10 to -13 . A region of dyad symmetry is indicated at nucleotides $641-661$ (underlined).

albicidin inactivation than extracts with the same total protein content from parallel cultures of $\mathrm{DH} 5 \alpha(\mathrm{pSB} 4)$ exposed to albicidin for only the final hour of incubation. Native PAGE revealed a corresponding increase in the cellular concentration of $a l b B$ gene product with increasing time of exposure to albicidin (Fig. 3).

\section{Nucleotide sequence of the albB gene}

The EcoRI/PvuII fragment of pSB12 contained a $620 \mathrm{bp}$ ORF that commenced about $0.1 \mathrm{~kb}$ from the EcoRI site. A potential ribosome-binding site with a GGAG Shine-
Dalgarno (SD) sequence (Shine \& Dalgarno, 1974; Stormo et al., 1982) was found $10 \mathrm{bp}$ upstream from an ATG assumed to act as the initiation codon (Fig. 4). The $\mathrm{N}$-terminal amino acid sequence of the $23 \mathrm{kDa}$ albicidin resistance protein produced by $\mathrm{pSB} 4$ corresponds to that predicted from this ORF. However, there are two additional in-frame ATG codons immediately downstream of the $\mathrm{SD}$ sequence, and another ORF commences at the ATG at base 5 and continues to base 592 in Fig. 4. Expression of the cloned gene in pSB4 indicates that there may be an effective promoter within the $100 \mathrm{bp}$ of cloned DNA upstream of the SD sequence, as there is no 


\section{B - MYDKYFSREELARLPLYTRGPD

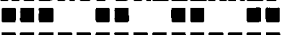 MYDRWFSOQELQVLPFADEDEQ}

Fig. 5. Comparison of 22 amino acids in the $\mathrm{N}$-terminal sequences of the $A$. denitrificans albB gene (B), and the $K$. oxytoca albA gene (A). Symbols: double dot, identical amino acids; single dot, amino acids with similar properties in their side chains.

recorded promoter activity in this direction in the polylinker of pUC19. The putative $A$. denitrificans promoter region did not conform well to the -35 and -10 consensus sequences for E. coli promoters, the best match being CTGGAT and TTCGAT (underlined in Fig. 4), centred approximately 50 and $27 \mathrm{bp}$, respectively, upstream of the start codon of the $A$. denitrificans gene.

A region of GC-rich dyad symmetry (Platt, 1986) occurred $20 \mathrm{bp}$ downstream from the termination codon TAG. This region would yield a potential hairpin loop structure of low stability $\left[-2.5 \mathrm{kcal} \mathrm{mol}^{-1}\left(-10.46 \mathrm{~kJ} \mathrm{~mol}^{-1}\right)\right]$ in the mRNA, but is not followed by consecutive thymidine residues or the TCTG consensus sequence characteristic of many factor-independent termination sites (Brendel \& Trifinov, 1984).

Computer analysis of the bacterial, plant and organelle genes in the GenBank database (Release 63) revealed no genes with close homology to the albB gene. When the computer analysis was conducted to allow regions to be realigned, there were regions of partial DNA homology between the $\mathrm{Alb}^{\mathrm{r}}$ genes from $A$. denitrificans and $K$. oxytoca. However, these regions are separated by deletions, insertions and frame-shifts so that translation results in dissimilar proteins.

Computer analysis of the NBRF protein sequence database (Release 40.0 ) revealed $62.5 \%$ homology at the $\mathrm{N}$ terminus of $\mathrm{Alb}^{\mathrm{r}}$ proteins of $A$. denitrificans and $K$. oxytoca. Fifteen of the first 16 amino acids of these albicidin binding proteins are either identical or have side chains with similar properties (Fig. 5). However, comparison of the entire sequence did not show even distant homology between the $A$. denitrificans $\mathrm{Alb}^{\mathrm{r}}$ protein and the K. oxytoca $\mathrm{Alb}^{\mathrm{r}}$ protein or any other protein (Lipman \& Pearson, 1985). Also, five of the eight identical amino acids at the $\mathrm{N}$ terminus of the two $\mathrm{Alb}^{\mathrm{r}}$ proteins used different codons.

\section{Deletion analysis of the promoter and $\mathbf{N}$ terminus regions}

To test the role of the possible promoter region between -24 and $-52 \mathrm{bp}$, deletions were made in this region of a subclone in plasmid vector pBluescriptII SK+. Two surprising results emerged. Firstly, deletion to $-14 \mathrm{bp}$ (which removes the putative $A$. denitrificans promoter) did not affect albicidin resistance (pSB6). Secondly, deletion

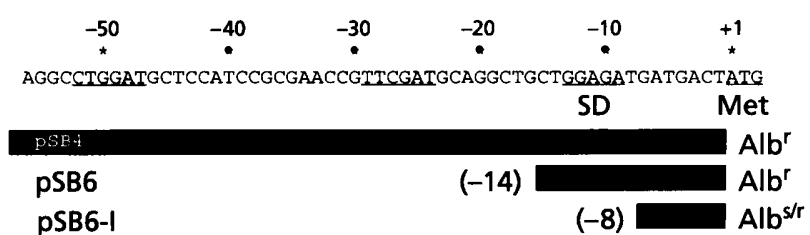

Fig. 6. Deletions introduced into the promoter region of the albB gene, and their effects on sensitivity to albicidin. The nucleotide sequence of the promoter region is shown at the top. Nucleotides are numbered from the translation-initiation site. Underlined upstream sequences indicate a putative SD sequence and regions of homology to prokaryote promoter consensus sequences. Lengths of the deleted clones after Exonuclease III digestions are shown by the lengths of the bars. E. coli $\mathrm{DH} 5 \alpha(\mathrm{pSB} 6-\mathrm{I})$ was resistant to albicidin only in the presence of IPTG, indicating transcription from the lac promoter.

to $-8 \mathrm{bp}$ (which also removes the putative promoter and $\mathrm{SD}$ sequence) abolished albicidin resistance, but resistance was partially restored when IPTG was added to induce the adjacent lac promoter (pSB6-I) (Fig. 6, Table 2). Sequencing across the vector/insert junctions showed that plasmid pSB6 carries the complete structural gene for the $\mathrm{Alb}^{\mathrm{r}}$ protein and its SD sequence as an out-of-frame transcriptional fusion behind the lac promoter. Thus the low level of constitutive expression from the lac promoter results in sufficient production of the $\mathrm{Alb}^{\mathrm{r}}$ protein to confer resistance.

Plasmid pSB6-I carries an in-frame translational fusion between the $\mathrm{N}$ terminus of the lac gene and the albB gene, driven by the lac promoter. Since it is in-frame with the lac gene, an additional 20 amino acids have been added to the $\mathrm{N}$ terminus of the normal $\mathrm{Alb}^{\mathrm{r}}$ gene product. The presence of these additional amino acids apparently interferes with the albicidin binding property of the gene product, so that albicidin resistance does not result from the low level of constitutive expression from the lac promoter. However, when the lac promoter is induced by IPTG, overproduction of the fusion protein partially restores albicidin resistance, possibly because the fusion protein has some residual albicidin binding activity, or due to removal of $\mathrm{N}$-terminal amino acids by intracellular protease activity, releasing a small amount of the effective $\mathrm{Alb}^{\mathrm{r}}$ protein. This is consistent with the indication from amino acid homology between $A$. denitrificans and $K$. oxytoca $\mathrm{Alb}^{\mathrm{r}}$ genes that the conserved $\mathrm{N}$ terminus may be important for albicidin binding.

The deletion in plasmid pSB7 extended to nucleotide 174 in the albB gene and an out-of-frame fusion, accounting for the loss of albicidin resistance. With pSB8, the gene product is an in-frame translational fusion with 17 amino acids from the lac $Z$ gene product fused to amino acid 86 of the albB gene product. This fusion protein lacked the conserved $\mathrm{N}$-terminal amino acids, and conveyed no albicidin resistance even when the lac promoter was induced by IPTG. This result is again consistent with the importance of the $\mathrm{N}$-terminal region for albicidin binding. 
Table 3. Binding of albicidin by the $a / b B$ gene product and a synthetic $N$ terminus oligopeptide

Results are means of two replicates at each albicidin concentration.

\begin{tabular}{|c|c|c|c|c|}
\hline \multirow[t]{2}{*}{ Treatment } & & \multicolumn{3}{|c|}{ Percentage inactivation of albicidin } \\
\hline & & $\begin{array}{l}\quad 400 \mathrm{ng} \\
\text { albicidin } \mathrm{ml}^{-1}\end{array}$ & $\begin{array}{l}200 \mathrm{ng} \\
\text { albicidin } \mathrm{ml}^{-1}\end{array}$ & $\begin{array}{l}100 \mathrm{ng} \\
\text { albicidin } \mathrm{ml}^{-1}\end{array}$ \\
\hline $\mathrm{H}_{2} \mathrm{O}$ control & & 0 & 0 & 0 \\
\hline pSB12 cell extract & $\left(4 \cdot 8 \mathrm{mg} \mathrm{ml}^{-1}\right)$ & 100 & 100 & 100 \\
\hline Oligopeptide & $\left(4.5 \mathrm{mg} \mathrm{ml}^{-1}\right)$ & 93 & 94 & 95 \\
\hline Oligopeptide & $\left(0 \cdot 45 \mathrm{mg} \mathrm{ml}^{-1}\right)$ & 50 & 56 & 50 \\
\hline
\end{tabular}

\section{Albicidin binding by a synthetic oligopeptide}

As a further test of the role of the conserved $\mathrm{N}$ terminus of the albicidin binding proteins from $A$. denitrificans and $K$. oxytoca, we tested the ability of a synthetic 20 amino acid oligopeptide MYDKYFSREELARLPLYTRG (identical to the $\mathrm{N}$ terminus of the $A$. denitrificans protein) to bind albicidin. At equivalent albicidin-protein ratios, albicidin binding by this oligopeptide was almost as effective as cell extracts from $E$. coli DH5 $\alpha(\mathrm{pSB} 12)$ (Table 3 ). However, based on visual estimates of band intensity on polyacrylamide gels (Fig. 3), the albB gene product constituted approximately $10 \%$ of total protein in these cell extracts. Therefore on a molar basis, binding by the synthetic oligopeptide was less efficient than for the full protein in cell extracts (Table 3 ).

\section{DISCUSSION}

Albicidin-resistant $A$. denitrificans isolated from soil carried a dominant gene which conferred albicidin resistance when expressed in $E$. coli. The isolated product of the resistance gene was a $23 \mathrm{kDa}$ protein which corresponded in molecular mass and N-terminal sequence to the predicted 206 amino acid polypeptide translated from the nucleotide sequence of the cloned gene. This protein was able to inactivate albicidin in vitro when recovered from non-denaturing gels. The protein lacked a signal sequence for transport across the cytoplasmic membrane (von Heijne, 1983). This may explain the presence of extracellular albicidin inactivation only in older cultures of $A$. denitrificans, where lysing cells would release some of the protein into the medium.

The $\mathrm{Alb}^{\mathbf{r}}$ protein from $A$. denitrificans appeared to inactivate albicidin by binding rather than covalently modifying the antibiotic, as previously observed with $K$. oxytoca (Walker et al., 1988). In both cases, a reducing agent was required for binding and albicidin inactivation was reversible following heat treatment of the albicidinprotein mixture. This indicates reversible binding of the resistance gene product to albicidin, to form a complex without antibiotic activity. Since albicidin is relatively heat stable, when the bound $\mathrm{Alb}^{\mathrm{r}}$ protein is denatured by heat treatment, most of the antibiotic activity is restored.
The possibility that binding is a pre-requisite to catalytic inactivation of albicidin has not previously been tested. Albicidin binding by the $A$. denitrificans $\mathrm{Alb}^{\mathrm{r}}$ protein in cell extracts was reversible by heat even after extended incubation (Fig. 2), and there was no progressive inactivation at albicidin-protein ratios resulting in some remaining antibiotic activity from unbound albicidin. This indicates no catalytic inactivation of albicidin under these assay conditions, but does not exclude the possibility that the gene product is an enzyme with a required cofactor lost during preparation of the cell extracts. To test this possibility, we measured albicidin recovery upon heating intact cells which had removed albicidin from the culture medium. Reversible albicidin binding, even after extended incubation in intact cells of $E$. coli $\mathrm{DH} 5 \alpha(\mathrm{pSB} 6)$ and $A$. denitrificans SO-9, confirmed the non-catalytic action of the $A$. denitrificans $\mathrm{Alb}^{\mathrm{r}}$ protein.

The regions of partial DNA sequence homology between the $A$. denitrificans and $K$. oxytoca $\mathrm{Alb}^{\mathrm{r}}$ genes indicate that there is an evolutionary relationship between the genes. However, sequence rearrangements have resulted in loss of homology at the amino acid level, except for a region of 16 amino acids at the $\mathrm{N}$ terminus, and codon usage is different even for identical amino acids of the two proteins in this region. There are also differences in the organization of the two $\mathrm{Alb}^{\mathrm{r}}$ genes. The $K$. oxytoca alb $A$ gene occurs in an operon, downstream of a gene for a $36 \mathrm{kDa}$ protein of unknown function (Walker et al., 1988), whereas in $A$. denitrificans the albB gene occurs immediately downstream of the promoter and overlaps a second ORF of unknown function for most of its length.

The sequence of the $A$. denitrificans promoter region deviates considerably from the canonical $E$. coli promoter. Exposure of E. coli DH5 $\alpha(\mathrm{pSB} 4)$ cells to albicidin resulted in a fivefold increase in albicidin inactivating ability within $6 \mathrm{~h}$, paralleled by an increase in the concentration of the $23 \mathrm{kDa}$ protein in cell extracts (Fig. 3). Because other plasmid-encoded proteins did not increase during this treatment, the effect was not due to plasmid amplification but rather to specific albicidin-induced production of the $\mathrm{Alb}^{\mathrm{r}}$ protein. We have not determined whether this induction involves regulation of transcription, translation, or protein stability. 
After a $6 \mathrm{~h}$ exposure to albicidin, the $\mathrm{Alb}^{\mathrm{r}}$ protein was estimated to comprise approximately $10 \%$ of the total protein in the E. coli $\mathrm{DH} 5 \alpha(\mathrm{pSB} 4)$ cell extract, based on band intensity after PAGE. On this basis, the observed inactivation of $30 \mathrm{ng}$ of albicidin ( $842 \mathrm{Da}$ ) by $10 \mu \mathrm{g}$ of cellular protein $\left(10 \% \mathrm{Alb}^{\mathrm{r}}\right.$ protein of $\left.23 \mathrm{kDa}\right)$ occurred at a molar ratio of 1 albicidin: $1 \mathrm{Alb}^{\mathbf{r}}$ protein.

We speculated that the amino acid homology in the $\mathrm{N}$ terminus of the $\mathrm{Alb}^{\mathrm{r}}$ proteins of $A$. denitrificans and $K$. oxytoca (Fig. 5) could indicate a conserved albicidin binding domain. Experiments with translational fusions and deletions confirmed the importance of the $\mathrm{N}$ terminus of the A. denitrificans $\mathrm{Alb}^{\mathrm{r}}$ protein for albicidin resistance (pSB6 to pSB8, Fig. 6, Table 2). A synthetic oligopeptide of 20 amino acids from the $\mathrm{N}$ terminus of the $A$. denitrificans $\mathrm{Alb}^{\mathrm{r}}$ protein also bound albicidin, but with lower efficiency than the full protein.

The normal role of the $A$. denitrificans albB gene is unknown, as we do not expect this organism to be naturally exposed to albicidin. The fate of bound albicidin in cells is also unknown. However, it is clear that binding can provide a high level of resistance to the antibiotic. Although albicidins are extremely potent antibacterial agents, effective at concentrations around $10 \mathrm{ng} \mathrm{ml} \mathrm{m}^{-1}$ (Birch \& Patil, 1985b), this depends on active accumulation by sensitive cells, resulting in much higher intracellular antibiotic concentrations (Birch et al., 1990). Expression of a binding protein with a high affinity for the antibiotic presumably keeps the free albicidin concentration in the cytoplasm below the level for lethal interaction with its target. Antibiotic-induced accumulation of the resistance gene product is clearly advantageous for this purpose, although the natural inducer and target of this intriguing mechanism in $A$. denitrificans is presumably a substance other than albicidin.

This detoxifying mechanism is encoded by a single gene, does not require complex cofactors for activity, operates rapidly and efficiently within cells, and results in a product of little or no toxicity. Thus, the albB gene seems suitable to be cloned into a suitable plant expression vector and transformed into sugarcane. Constitutive expression of the gene, and production of the corresponding protein in the cytosol should result in binding and inactivation of albicidin before it reaches its target in the plastids. This should allow a test of the hypothesis that albicidin sensitivity is important for leaf scald disease sensitivity in sugarcane. In the longer term, the gene might be expressed from an albicidin-inducible promoter to convey efficient resistance in sugarcane against leaf scald disease caused by albicidin-producing strains of $X$. albilineans.

\section{ACKNOWLEDGEMENTS}

The authors are grateful for advice and assistance from Dr A. Chris Hayward on identification of Alb ${ }^{r}$ bacteria, Dr John M. Pemberton on $\mathrm{Alb}^{\mathrm{r}}$ gene cloning, and $\mathrm{Dt}$ Ross Smith on protein characterization. We thank Amanda Walmsley and Dr Lian-Hui Zhang for the experiments on albicidin binding by a synthetic oligopeptide and intact cells. This work was supported by the
Australian Research Council and by a scholarship to W. V.S.B under the Colombo Plan for Technical Co-operation administered by the Australian International Development Assistance Bureau.

\section{REFERENCES}

Birch, R. G. \& Patil, S. S. (1983). The relation of blocked chloroplast differentiation to sugarcane leaf scald disease. Phytopatbology 73, 1368-1374.

Birch, R. G. \& Patil, S. S. (1985a). Antibiotic and process for the production thereof. USA Patent 4525354, 25 June 1985.

Birch, R. G. \& Patil, S. S. (1985b). Preliminary characterization of an antibiotic produced by Xanthomonas albilineans which inhibits DNA synthesis in Escherichia coli. J Gen Microbiol 131, 1069-1075.

Birch, R. G. \& Patil, S. S. (1987a). Correlation between albicidin production and chlorosis induction by Xanthomonas albilineans, the sugarcane leaf scald pathogen. Physiol Molec Plant Pathol 30, 199-206.

Birch, R. G. \& Patil, S. S. (1987b). Evidence that an albicidin-like phytotoxin induces chlorosis in sugarcane leaf scald disease by blocking plastid DNA replication. Physiol Molec Plant Pathol 30, 207-214.

Birch, R. G., Pemberton, J. M. \& Basnayake, W. V. S. (1990). Stable albicidin resistance in Escherichia coli involves an altered outer membrane nucleoside uptake system. J Gen Microbiol 136, 51-58.

Bower, R. \& Birch, R. G. (1992). Transgenic sugarcane plants via microprojectile bombardment. Plant J 2, 409-416.

Bradford, M. (1976). A rapid and sensitive method for the quantification of mictogram quantities of protein using the principle of protein-dye binding. Anal Biochem 72, 248-254.

Brendel, V. \& Trifinov, E. N. (1984). A computer algorithm for testing potential prokaryotic terminators. Nucleic Acids Res 12, 4411-4427.

Chen, E. Y. \& Seeburg, P. H. (1985). Supercoil sequencing: a fast and simple method for sequencing plasmid DNA. DNA 4, 165-170.

Franks, T. \& Birch, R. G. (1991). Gene transfer into intact sugarcane cells using microprojectile bombardment. Aust J Plant Pbysiol 18, 471-480.

Fsihi, H., Kottwitz, B. \& Bremer, E. (1993). Single amino acid substitutions affecting the substrate specificity of the Eschericbia coli K-12 nucleoside-specific Tsx channel. J Biol Chem 268, 1749517503.

von Heijne, G. (1983). Patterns of amino acids near signal-sequence cleavage sites. Eur J Biochem 133, 17-21.

Hohn, B. \& Collins, J. (1980). A small cosmid for efficient cloning of large DNA fragments. Gene 11, 291-298.

Holloway, P. J. \& Arundel, P. H. (1988). High resolution twodimensional electrophoresis of plant proteins. Anal Biochemistry $172,8-13$.

Houghten, R. A. (1985). A general method for the rapid solid phase synthesis of large numbers of peptides. Proc Natl Acad Sci US A 82, 5131-5135.

Krieg, N. R. \& Holt, J. G. (eds) (1984). Bergey's Manual of Systematic Bacteriology, vol. 1. Baltimore: Williams \& Wilkins.

Kyte, J. \& Doolittle, R. F. (1982). A simple method for displaying the hydropathic character of a protein. J Mol Biol 157, 105-132.

Lewin, B. (1990). Genes IV. Oxford: Oxford University Press.

Lipman, D. J. \& Pearson, W. R. (1985). Rapid and sensitive protein similarity search. Science 227, 1435-1441. 
Miller, J. H. (1972). Experiments in Molecular Genetics. Cold Spring Harbor, NY: Cold Spring Harbor Laboratory.

Platt, T. (1986). Transcription termination and the regulation of gene expression. Annu Rev Biochem 55, 339-372.

Priefer, U., Simon, R. \& Puhler, A. (1984). Cloning with cosmids. In Advanced Molecular Genetics, pp. 190-201. Edited by A. Pühler \& K. N. Timmis. Berlin: Springer-Verlag.

Rathus, C. \& Birch, R. G. (1992). Stable transformation of callus from electroporated sugarcane protoplasts. Plant Sci 82, 81-89.

Ryrie, I. J. (1983). Immunological evidence for apoproteins of the light-harvesting chlorophyll-protein complex in a mutant of barley lacking chlorophyll b. Eur J Biochem 131, 149-155.

Sambrook, J., Fritsch, E. F. \& Maniatis, T. (1989). Molecular Cloning: A Laboratory Manual, 2nd edn. Cold Spring Harbor, NY: Cold Spring Harbor Laboratory.

Shine, J. \& Dalgarno, L. (1974). The 3-terminal sequence of Escherichia coli $16 \mathrm{~S}$ ribosomal RNA : complementarity to nonsense triplets and ribosome binding sites. Proc Natl Acad Sci US A 71, 1342-1346.

Stormo, G. D., Schneider, T. D. \& Gold, L. M. (1982). Characterization of translational initiation sites in Escherichia coli. Nucleic Acids Res 10, 2971-2996.

Uhlin, B. E., Schweickart, V. \& Clark, A. J. (1983). New runaway replication-plasmid cloning vectors and suppression of runaway replication by novobiocin. Gene 22, 255-265.

Vieira, J. \& Messing, J. (1982). The pUC plasmids, an M13mp7derived system for insertion mutagenesis and sequencing synthetic universal primers. Gene 19, 259-268.

Walker, M. J., Birch, R. G. \& Pemberton, J. M. (1988). Cloning and characterization of an albicidin resistance gene from Klebsiella oxytoca. Mol Microbiol 2, 443-454.

Received 12 August 1994; revised 21 October 1994; accepted 26 October 1994 